\title{
COLONIC CARCINOID TUMORS: a clinicopathologic study of 23 patients from a single institution
}

\author{
Daniel Reis WAISBERG'1 Antonio Sergio FAVA'1 ${ }^{1}$, Lourdes Conceição MARTINS', \\ Leandro Luongo MATOS ${ }^{1}$, Maria Isete Fares FRANCO${ }^{2}$ and Jaques WAISBERG' ${ }^{1}$
}

\begin{abstract}
Context - Colonic carcinoids, excluding those arising in the appendix, have proved to be extremely rare. Due to their rarity, the characteristics and behavior of this unusual malignancy remain unclear. Objective - To review the clinicopathologic features of patients operated on carcinoid tumors of the colon. Methods - Twenty-three patients (12 males and 11 females) were operated on colonic carcinoids. The mean age of the patients was $63.0 \pm 12.9$ years (42 to 85 years). The clinical and histopathological data of patients who were pathologically diagnosed as having carcinoid tumors and submitted to surgical treatment over a 30-year period (1977-2007) were gathered. Actuarial patient survival was estimated using the Kaplan-Meier method, with carcinoid-specific death as the outcome. Results - The mean time elapsed between onset of symptoms and surgical treatment was 8.3 months (1.5 to 20 months). The most frequent symptoms or signs encountered were abdominal pain followed by anorexia or weight loss, diarrhea, abdominal tenderness, palpable abdominal mass, and rectal bleeding. No carcinoid syndrome was noted. The lesion was located in the cecum in $16(69.6 \%)$ patients, in the sigmoid in 3 patients $(13.0 \%)$, in the ascending colon in 3 patients $(13.0 \%)$, and in the transverse colon in one patient $(4.3 \%)$. Twenty-one $(91.3 \%)$ patients were operated on curative intent. Spreading of the disease to the liver and peritoneum was found in two $(8.7 \%)$ patients who submitted to intestinal bypass. The mean size of the largest mass was $3.7 \pm 1.2 \mathrm{~cm}$ ( 1.5 to $6.2 \mathrm{~cm}$ ). There were multiple (two or more) lesions in three cases $(13.0 \%)$. In the resected cases, the lymph nodes were compromised in 10 patients $(47.6 \%)$ and disease-free in $11(52.4 \%)$. Venous invasion and neural infiltration were both present in five $(23.8 \%)$ patients. The tumors had penetrated the muscularis propria in all resected cases. Four (17.4\%) patients had a second non-carcinoid primary tumor. Three $(13.0 \%)$ patients died due to postoperative complications and five $(21.7 \%)$ patients died from metachronous metastases or local recurrence. Fifteen patients $(65.2 \%)$ remain alive without evidence of active disease. The mean follow-up period was 12 years (1.2 to 18 years), whereas the mean global survival was $50.7 \pm 34.2$ months and the crude survival rate at 5 years was $62.7 \%$. Conclusions - Carcinoid tumors of the colon are frequently right-sided and may be clinically occult until an advanced stage is reached. Based on the relatively poor survival rates reported, it is recommended that, in addition to standard surgical resection, vigorous surveillance for metastatic disease must be performed, particularly during the first 2 years after surgery. In addition, these patients require evaluation of the entire gastrointestinal tract for evidence of coexisting malignancy, along with an extended period of follow-up, because tumor recurrences after 5 years are not uncommon.
\end{abstract}

HEADINGS - Colorectal neoplasms. Carcinoid tumor. Carcinoma, neuroendocrine.

\section{INTRODUCTION}

Carcinoid tumors (well-differentiated endocrine tumors), a heterogeneous group of rare neoplasms with neuroendocrine features found in the gastrointestinal tract, the ovaries, and the lungs, are the most intriguing and most commonly encountered tumors of the diverse neuroendocrine tumor group ${ }^{(12,14,18,20,21,22)}$. They may produce a variety of hormones and have a variable histological pattern and biologic behavior ${ }^{(20,22,30,31)}$.

Colonic carcinoids, excluding those arising in the appendix, have proved to be extremely rare and have mostly been the subject of case reports. To date, only single papers presenting occasional larger series of patients have been published ${ }^{(3,7,24,27)}$. To the best of our knowledge, there is currently only one clinicopathological study of colonic carcinoids (rectal carcinoids not included) that has been published, which included cases of this disease within the whole population of a state(24). Thus, the present study represents the first large series of colonic carcinoids from a single institution.

Colonic carcinoids exhibit the worst prognosis among all gastrointestinal carcinoid tumors, probably because of the large tumor size at the time of diagnosis and the high percentage of metastases ${ }^{(27)}$ Thus, the 
characteristics and behavior of this unusual malignancy remain unclear since the few studies in the literature fail to correlate clinical presentation and histopathology with outcome. Moreover, as these carcinoids are relatively uncommon, accurate information on their clinical-pathological features and treatment outcomes have been limited.

The purpose of the present study was to present a retrospective analysis of the clinical aspects, diagnosis, histopathological features, management, and prognosis of patients with carcinoid tumors of the colon operated on our institution.

\section{METHODS}

A total of 26 patients with colonic carcinoids, confirmed by histopathological and immunohistochemistry examinations, were treated in the Department of Surgery of "Hospital do Servidor Público Estadual”, São Paulo, SP, Brazil, over the 30-year period from 1977 to 2007. Of these, three were excluded from the study because they were not operated on due to serious associated diseases. Thus, the data from this sample represents a review of 23 patients operated on colonic carcinoids in a single institution. Cases of ileocecal carcinoids were included, since the cecal side of the valve appeared to be predominantly involved. On the other hand, cases of appendiceal or rectal carcinoids were not included in this series.

The clinical course of these patients was obtained from a review of the hospital records and from interviews with the patients or their relatives. Survival was calculated from the time of the operation until the last follow-up or death.

Twelve $(52.2 \%)$ of the patients were male and $11(47.8 \%)$ were female, with no difference in disease prevalence between genders. The mean age of the patients was $63.0 \pm 12.9$ years, ranging from 42 to 85 years, with a peak incidence in the 7 th decade. All the patients were Caucasian.

The staging was carried out from the physical examination findings, colonoscopy and the respective biopsy, rectosigmoidoscopy, barium enema, ultrasonography, computed tomography of the abdomen, radiography of the chest, laparotomy, and histopathological and immunohistochemistry examinations of specimens from the surgical extirpation.

The original slides of the colonic carcinoid tumors were reviewed by a pathologist and, whenever necessary, further slices were cut from the paraffin blocks. Hematoxylin and eosinstained sections of the tumor were assessed for outer level of invasion, histological pattern, lymphatic or vascular invasion, neural invasion, and mitotic rate. Immunohistochemical stain, when used, was carried out with the avidin-biotin technique.

Potential prognostic factors of tumor features such as location, diameter, number of lesions, and histologic findings were evaluated. Similarly, the clinical aspects such as patient age and gender, clinical symptoms, methods of diagnosis, presence of synchronous or metachronous metastases, second primary malignance, treatment, recurrence, and survival were analyzed.
Quantitative variables were represented by absolute frequency $(\mathrm{N})$, relative frequency $(\%)$, and arithmetic mean. Actuarial patient survival was estimated using the KaplanMeier method, with carcinoid-specific death as the outcome. Patients who died from other causes or remained alive at the most recent follow-up were treated as censored in this analysis.

\section{RESULTS}

The mean time elapsed between onset of symptoms and the surgical treatment was 8.3 months, ranging from 1.5 to 20 months. The most frequent symptoms encountered were abdominal pain $(86.9 \%)$ on the same side as the tumor, followed by anorexia or weight loss $(52.1 \%)$, diarrhea $(52.1 \%)$, and rectal bleeding $(21.7 \%)$. Mean weight loss was $6.5 \mathrm{~kg}$ and the most common physical signs were abdominal tenderness and palpable abdominal mass, present in six $(26.1 \%)$ cases. No carcinoid syndrome was noted in the patients of this series.

The preoperative diagnosis was obtained in four $(17.4 \%)$ patients by colonoscopy and biopsy of the suspect lesion. The remaining patients had their definitive diagnosis established by histopathological or immunohistochemical studies of specimens from the surgical extirpation or intra-operative biopsies. Pre-operative CEA serum levels were normal in all patients. Urinary 5-hidroxyindoleacetic acid (5-HIAA) concentration was measured in four (17.4\%) patients and was found to be normal in all cases.

The lesion was located in the cecum in $16(69.6 \%)$ patients, in the sigmoid in $3(13.0 \%)$ patients, in the ascending colon in $3(13.0 \%)$ patients, and in the transverse colon in $1(4.3 \%)$ patient. Thus, the majority $(82.6 \%)$ of the lesions were located in the proximal colon. Eighteen $(78.2 \%)$ patients were free of metastatic disease and were operated on curative intent. In three $(13.0 \%)$ patients, synchronous metastases (two in the liver and one in the ovary) were disclosed in the laparotomy and resected with the corresponding large bowel with curative intent. The extent of the colonic extirpation varied according to the location of the lesion and the presence of advanced local disease: right hemicolectomy in $16(69.5 \%)$ patients, anterior rectosigmoidectomy in $3(13.0 \%)$ patients, left hemicolectomy in $1(4.3 \%)$ patient, and total colectomy in $1(4.3 \%)$ patient. Disseminated disease to the liver and peritoneum was found in two $(8.7 \%)$ patients who were submitted to intestinal bypass. Four $(17.4 \%)$ patients received chemotherapy with intravenous 5-fluorouracil, while one patient with hepatic metastases received adriamicin via the hepatic artery in a chemoembolization protocol.

The mean size of the largest dimension for colonic carcinoids was $3.7 \pm 1.2 \mathrm{~cm}$, ranging from 1.5 to $6.2 \mathrm{~cm}$. A mean size of $4.0 \mathrm{~cm}$ was noted for those carcinoids without metastatic disease and $3.3 \mathrm{~cm}$ for those with metastases. Nineteen $(82.6 \%)$ patients with a colonic carcinoid had a tumor diameter greater than $2.0 \mathrm{~cm}$. Concerning the cases submitted to tumor resection, there was a single lesion in 18 $(85.7 \%)$ cases and multiple (two or more) lesions in 3 cases $(14.3 \%)$. 
In the resected cases, the lymph nodes were compromised by the tumor in $10(47.6 \%)$ and free in $11(52.4 \%)$. Venous invasion and neural infiltration were both present in five $(23.8 \%)$ patients each. The histological picture was typical for carcinoids across all tumors (Figures 1 and 2). The most common histological patterns were trabecular, insular, glandular, and mixed. The mitotic rate was generally low, except for metastasizing lesions. The tumors had penetrated the muscularis propria in all resected cases. The depth of invasion, according to the TNM classification, was T2 in 3 $(14.3 \%)$ patients, T3 in $15(71.4 \%)$ patients, and T4 in $3(14.3 \%)$ patients. Immunohistochemical studies were performed in histological samples of $15(65.2 \%)$ patients and disclosed chromogranin and/or neuron-specific enolase positive staining, mostly diffuse and occasionally focal (Figure 3).

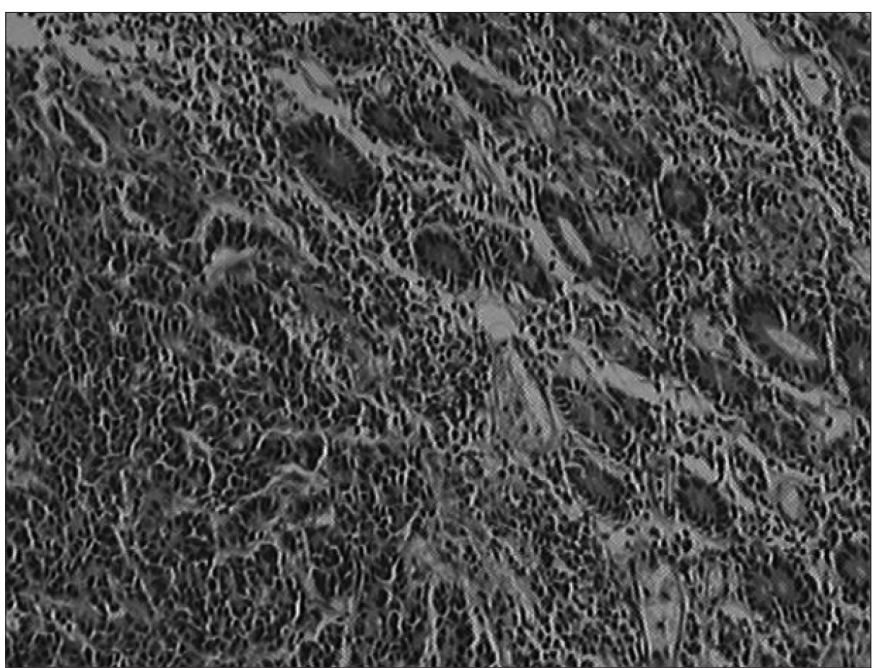

FIGURE 1. Colonic carcinoid with glands, trabecular and solid patterns (Hematoxylin and eosin, original magnification X200)

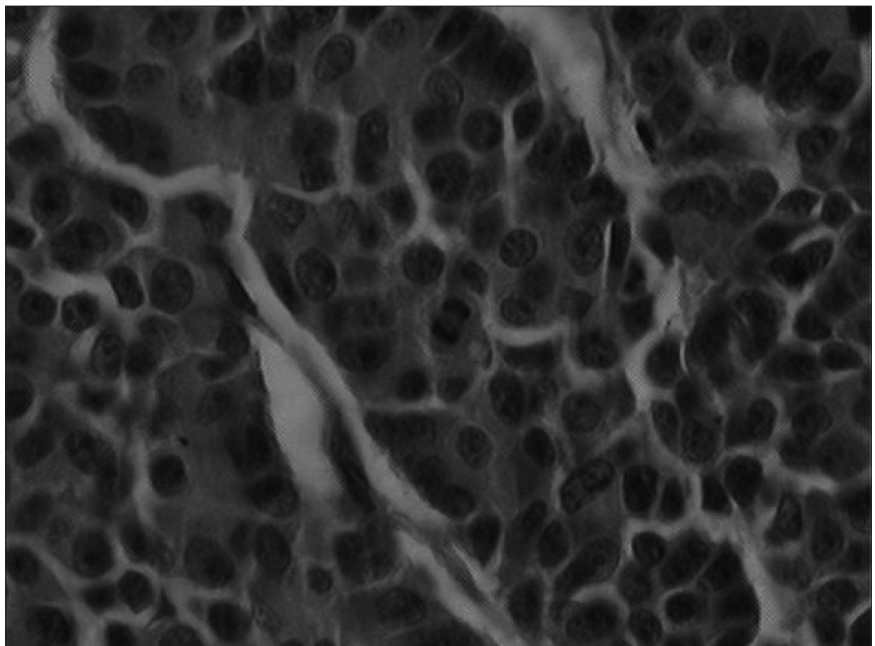

FIGURE 2. Colonic carcinoid. Round and ovoid hyperchromatic cells with acidophilic cytoplasm having ill-defined cytoplastic borders and uniform cells pattern. (Hematoxylin-eosin, original magnification X400)

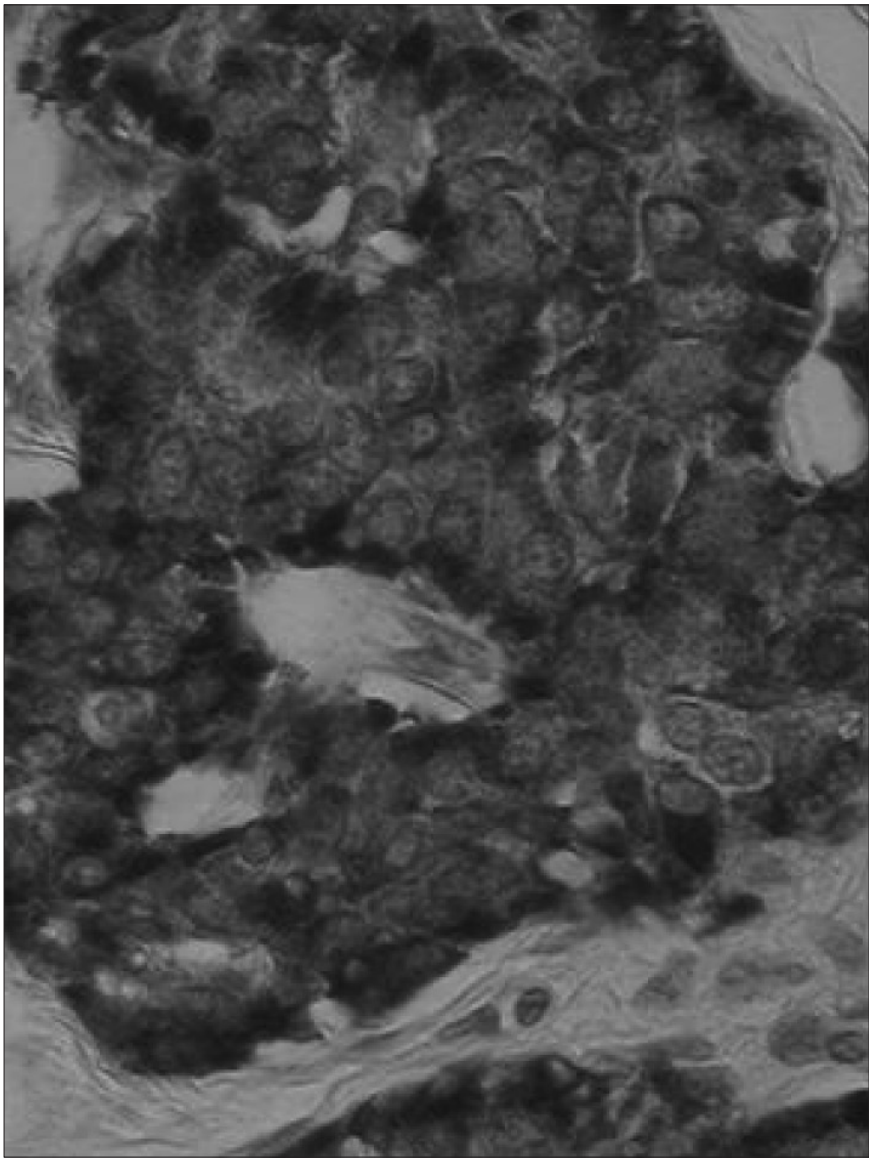

FIGURE 3. Colonic carcinoid. Immunohistochemical staining showing the majority of tumor cells stains strongly with chromogranin in the cytoplasm (avidin-biotin complex - peroxidase method, staining with chromogranin A, original magnification X400)

There were four $(17.4 \%)$ patients with seven second primary malignancies: two synchronous and five metachronous lesions. The synchronous tumors numbered two carcinomas of the sigmoid, while there were five metachronous lesions: one melanoma and four carcinomas (skin, bladder, prostate, and uterus). One of these patients disclosed one synchronous (carcinoma of the sigmoid) and two metachronous (carcinoma of the bladder and uterus) tumors.

From the 23 cases of this series, $8(34.7 \%)$ patients died and $15(65.2 \%)$ remain alive without evidence of active disease. Three $(13.0 \%)$ patients died because of postoperative complications and in all of them the disease was disseminated. A further five $(21.7 \%)$ patients died from metachronous metastases or local recurrence of the tumor: three in the peritoneum, one in the liver, and another in the lungs. One patient submitted to a right colectomy had a recurrence in the small bowel near the ileocolic anastomosis 1 year after the resection of a carcinoid tumor in the proximal colon. This patient was re-resected and survived without active disease. Thus, the recurrence rate in this series was $26.1 \%(n=6)$. 
The mean follow-up period was 12 years (1.2 to 18 years). The mean global survival was $50.7 \pm 34.2$ months and the crude survival rate at 5 years reached $62.7 \%$ (Figure 4 ).

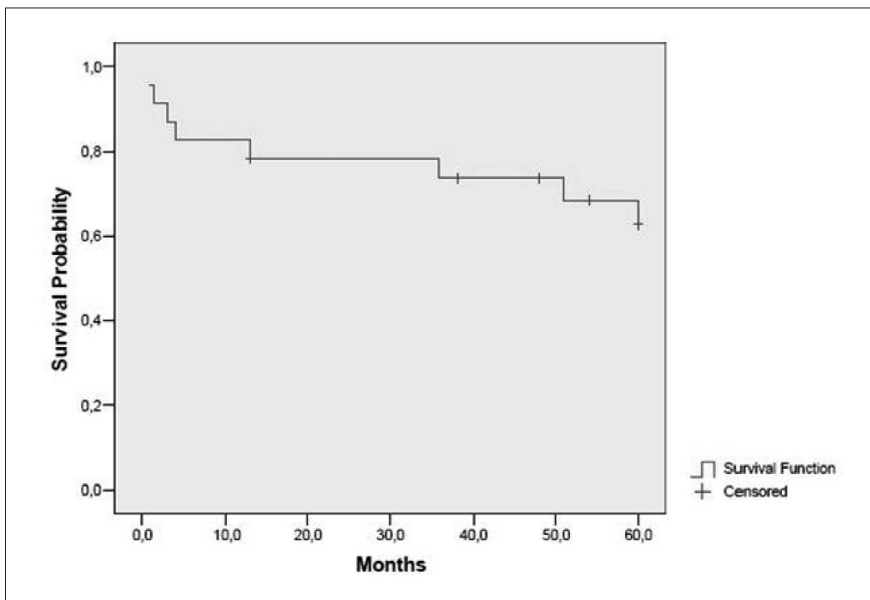

FIGURE 4. Actuarial survival curve of patients with colonic carcinoids (Kaplan-Meier plot estimating cumulative risk)

\section{DISCUSSION}

The percentage of all gastrointestinal carcinoid tumors located in the colon has been reported to range from $0.6 \%$ to $7 \%(12,14,18,20,24,27)$, whereas colonic carcinoids account for less than $1 \%$ of all colorectal tumors ${ }^{(14,18,28)}$. Carcinoids of the colon tend to occur in older persons where more than $70 \%$ are older than 50 years of age. The peak incidence is during the 7th decade of life ${ }^{(2,4,5,27,31)}$. Gender distribution shows a slight female predominance ${ }^{(2,3,4,7,21,24,27)}$. This series also encountered prevalence in individuals older than 50 years $(87 \%)$, but the incidence was equal in male and female, probably due to the size of the patient sample.

The clinical manifestations of colonic carcinoid tumors mimic those of any colonic cancer hampering its preoperative appraisal ${ }^{(7,10,24,25)}$. They are frequently rightsided and may be clinically occult until an advanced stage is reached, at which point they become bulky ${ }^{(1,8,18,20,21,25)}$. The predominance of enterocromaffin cells in the right colon account for the greater number of colon carcinoids on the right side ${ }^{(21,26)}$ as reported in the present study. The mean time elapsed of 8.3 months between onset of symptoms and the surgical treatment observed in this series illustrates this difficulty in diagnosis. These tumors are most often small, bulky, confined to the submucosa, slow-growing, and show a typical trabecular structure ${ }^{(2,4}$ $7,13,15,17,24)$, as also observed in the present series. A more undifferentiated pattern is associated with clinically more aggressive features ${ }^{(6,20)}$. Carcinoid tumors confined to the mucosa and submucosa are considered non-invasive ${ }^{(6,13)}$. They became invasive when penetrating the seromuscular wall and spreading to the regional lymphatic and blood streams ${ }^{(5)}$. All of the colonic carcinoid tumors in our study involved the muscularis propria and were considered invasive.

In our series, the average size of the lesions was $3.7 \pm 1.2$ $\mathrm{cm}$, ranging from 1.5 to $6.2 \mathrm{~cm}$, and only two lesions were $<2$ $\mathrm{cm}$, being comparable to previous studies' finding $\mathrm{s}^{(4,7,11,24)}$. In contrast to those described in other studies ${ }^{(7,16,24)}$, a mean size of $4.0 \mathrm{~cm}$ was noted for those carcinoids without metastatic disease, and $3.3 \mathrm{~cm}$ for those with metastases. Although tumor size and microinvasiveness are the main prognostic factors in gastrointestinal carcinoids ${ }^{(18,20,25)}$, these criteria are of little importance in the assessment of the prognosis of colonic tumors because the majority of the lesions exceed a size of $2 \mathrm{~cm}$ and involve the muscularis propria at presentation ${ }^{(27)}$.

Colonic carcinoid tumors are usually nonfunctioning, but occasionally serotonin-producing tumors have been observed in the colon ${ }^{(7,24)}$. Neuron-specific enolase and serotonin are the most frequently noted immunohistochemical positive stains in carcinoid tumors of the colon ${ }^{(22)}$. In the immunohistochemical study performed on $15(65.2 \%)$ tumors in this series, all disclosed chromogranin and/or neuron-specific enolase positive staining.

The most important features of carcinoids of the colon were that, at the time of presentation, they were large, mostly in the cecum and ascending colon, and had reached an advanced stage ${ }^{(4,7,24)}$. In this series, the high proportion of compromised lymph nodes, the deep penetration of the tumor into the intestine wall, and the elevated number of distant and peritoneal metastases evidenced the advanced stage at operative treatment.

Metastatic disease occurs more frequently with carcinoids of the colon than with those at other sites ${ }^{(3,16)}$. This can probably best be explained by the larger size this tumor attains in the colon before becoming symptomatic, with advanced stage rather than biologic aggressiveness ${ }^{(3,7,16,24)}$. Metastasis at the time of the first operation is found in $50 \%$ to $71 \%$ of patients with colonic carcinoids ${ }^{(24)}$ compared with $22 \%$ for carcinoma of the colon ${ }^{(28)}$. Indeed, in the current study, the presence of metastases including the involvement of lymph nodes reached $62.2 \%$ of all cases.

The only effective treatment available for carcinoid tumors of the colon is surgical ${ }^{(3,4,7,23)}$. Carcinoids of the colon larger than $2.0 \mathrm{~cm}$ appear to behave like aggressive malignant neoplasms ${ }^{(3,9,10,16,21,24)}$. Nevertheless, unlike rectal carcinoids, the size of the lesion and the presence of tumor invasion into the muscularis propria does not always indicate the possible presence or absence of metastases, and does not prove a useful prognostic factor for colonic carcinoids $s^{(3,16,24)}$, a finding also observed in the present study. For practical purposes, colon carcinoids should be managed as if they were carcinomas of the colon ${ }^{(21,24)}$.

Isolated hepatic metastases should also be $\operatorname{resected}^{(2,7,12,}$ 18, 24), and this procedure was performed in two cases in the present series, both of whom remain alive without active disease. If resectable, widespread metastatic disease does not contraindicate removal of the primary tumor ${ }^{(4,7,24)}$, as occurred in this series for a patient with carcinoid tumor of 
the cecum, ovarian metastases, and peritoneal spread who reached 13-month survival.

Although not observed in this series, less than $5 \%$ of colonic carcinoids cause the carcinoid syndrome ${ }^{(3,4,24)}$. In patients with the carcinoid syndrome, palliative resections or aggressive surgical debulking to decrease the mass of the tumor significantly improved the condition of some patients, sometimes obliterating the manifestations of the syndrome and prolonging life $\mathrm{l}^{(2,4,7,24)}$.

The perioperative mortality rate in our series was $13.0 \%$. The mortality rate was high because the patient population was elderly and had multiple associated medical problems or widespread metastatic disease. Our rate, however, is comparable to the $19 \%$ perioperative mortality rate cited by ROSENBERG and WELCH ${ }^{(26)}$.

In the majority of studies of gastrointestinal carcinoids, colonic carcinoid tumors have been found to have the poorest survival rates ${ }^{(12,14,18,20,21,27)}$. Moreover, the survival rates of patients with carcinoids of the colon are worse than those of patients with carcinoma of the colon ${ }^{(28)}$. Carcinoids in the left colon were diagnosed at an earlier stage than carcinoids of the right colon $^{(2,3,4,7,24)}$. As a result, the 5-year survival rate is higher for those patients with left-sided lesions compared to patients with right-sided lesions. The crude survival rates are $51 \%-56 \%$ at 2 years, $20 \%-52 \%$ at 5 years, and $10 \%$ at 10 years $^{(3,9,24,27)}$ and are comparable with the survival of $62.7 \%$ at 5 years found in the present series.

In addition to its malignant potential and production of biologically active substances, patients diagnosed with carcinoid tumors are at increased risk between $25 \%$ to $46 \%$ of developing a second non-carcinoid primary tumor ${ }^{(9,11,19 \text {, }}$
24). Most of the synchronous lesions were observed in the gastrointestinal tract, yet most of the metachronous cancers were observed outside the gastrointestinal $\operatorname{tract}^{(9,11,24,29)}$. Four $(17.4 \%)$ patients with second primary malignances were observed in this series: two synchronous carcinomas of the sigmoid, one metachronous bladder carcinoma, and another metachronous prostate carcinoma. It is important to recognize that this second lesion could develop in sites remote from the colon ${ }^{(29)}$. Thus, follow-up should include all of the sites at risk including the rest of the gastrointestinal tract, the lungs, prostate, and urinary system. Because the second primary lesion is usually the more aggressive malignancy, most carcinoid patients with a second malignancy do not die from the carcinoid tumor, but from the second tumor ${ }^{(9)}$.

Although a rare entity, carcinoid tumors of the colon represent a challenge to the colorectal surgeon. They are frequently right-sided and may be clinically occult until an advanced stage is reached. Based on the relatively poor survival rates reported, it is recommended that, in addition to standard surgical resection, vigorous surveillance for metastatic disease must be performed, particularly during the first 2 years after surgery. In addition, these patients require evaluation of the entire gastrointestinal tract for evidence of coexisting malignancy along with an extended period of follow-up because tumor recurrences after 5 years are not uncommon.

Further series of colonic carcinoids need to be studied to provide basic insights into the elucidation of the biologic parameters to allow a more comprehensive clinical course, facilitate diagnosis, disclose principal prognostic factors, and indicate therapeutic modalities of these fascinating, unusual, but as yet poorly understood neoplasms.

Waisberg DR, Fava AS, Martins LC, Matos LL, Franco MIF, Waisberg J. Tumores carcinóides do cólon: estudo clinicopatológico de 23 doentes de uma única instituição. Arq Gastroenterol. 2009;46(4):288-93.

RESUMO - Contexto - Carcinóides cólicos, excluindo aqueles que se originam no apêndice cecal, são extremamente raros. Devido a esta raridade, as características e comportamento desta neoplasia permanecem indefinidas. Objetivo - Rever as características clinicopatológicas de doentes operados por carcinoma cólico. Método - Vinte e três doentes (12 homens e 11 mulheres) foram operados. A média de idade dos doentes foi de 63,0 $\pm 12,9$ anos ( 42 a 85 anos). Os dados clínicos e histopatológicos dos doentes com diagnóstico patológico de tumor carcinóide e submetidos ao tratamento cirúrgico no período de 30 anos (19772007) foram obtidos a partir dos prontuários. A sobrevivência atuarial dos doentes foi estimada pelo método de Kaplan-Meier, considerando-se como óbito específico aquele devido ao tumor carcinóide. Resultados - A média de tempo decorrida entre o início dos sintomas e o tratamento cirúrgico foi de 8,3 meses (1,5 a 20 meses). O sintoma mais frequente encontrado foi dor abdominal seguida por anorexia ou perda de peso, diarréia, massa abdominal palpável e sangramento pelo reto. Não foram observados doentes com síndrome carcinóide. A lesão estava localizada no ceco em 16 (69,6\%) doentes, no cólon sigmóide em 3 (13,0\%), no colo ascendente em 3 (13,0\%) e no cólon transverso em 1 (4,3\%). Vinte e um (91,3\%) doentes foram operados com intenção curativa. Disseminação da doença para o fígado e peritônio foi encontrada em dois $(8,7 \%)$ doentes que foram submetidos ao desvio intestinal. A média do tamanho das lesões intestinais foi 3,7 $\pm 1,2 \mathrm{~cm}$ (1,5 a 6,2 cm). Lesões múltiplas (duas ou mais) ocorreram em três (13,0\%) casos. Nas lesões ressecadas, os linfonodos estavam comprometidos em $10(47,6 \%)$ e livres em 11 (52,4\%). Invasão venosa e infiltração neural estavam ambas presentes em cinco $(23,8 \%)$ doentes. A neoplasia penetrava a muscularis propria em todos as lesões ressecadas. Quatro $(17,4 \%)$ doentes apresentaram outra neoplasia maligna primária. Três $(13,0 \%)$ doentes faleceram devido a complicações pós-operatórias e outros cinco $(21,7 \%)$ morreram devido às metástases metacrônicas ou recidiva local. Quinze doentes $(65,2 \%)$ permanecem vivos e sem sinais de doença ativa. A média do período de seguimento foi de 12 anos (1,2 a 18 anos), a média de tempo de sobrevivência foi de 50,7 $\pm 34,2$ meses e o índice de sobrevivência de 5 anos foi $62.7 \%$. Conclusões - Os tumores carcinóide do cólon localizam-se, geralmente, no cólon direito e podem ser clinicamente ocultos até que atinjam estádios avançados. Devido ao índice relativamente baixo de sobrevivência, é recomendado que, além da ressecção cirúrgica padronizada, seja realizada vigilância intensa para doença metastática, especialmente durante os 2 primeiros anos após a operação. Doentes com carcinóide do cólon necessitam de avaliação de todo o trato gastrointestinal para verificar a presença de outras neoplasias malignas primárias, além de seguimento pós-operatório por período maior de tempo, pois a recidiva após 5 anos não é incomum.

DESCRITORES - Neoplasias colorretais. Tumor carcinóide. Carcinoma neuroendócrino. 


\section{REFERENCES}

1. Accetta I, Accetta P, Maia F, Palombo A, Fainstein C, Caparica Filho A. Tumores carcinóides no tubo digestivo. Folha Méd. 1991;103:111-2.

2. Ahlberg J, Bergstrand O, Holmstrom B, Ullman J, Wallberg P. Carcinoids of the colon and rectum in patients aged 30 and younger. Acta Chir Scand Suppl. 1980;500:33-5.

3. Ballantyne GH, Savoca PE, Flannery JT, Modlin IM. Incidence and mortality of carcinoids of the colon. Data from the Connecticut Tumor Registry. Cancer. 1992;69:2400-5.

4. Bartos M, Narebski JM, Kaczka K, Pomorski L. Colorectal carcinoid tumors-own experience. Neoplasma. 2000;47:409-12.

5. Bautista LI, Collins RA. Four cases of malignant colon carcinoid. Int Surg. 1982;67:488-90.

6. Bromberg SH, Reis Jr PM, Waisberg J, França LCM, Godoy AC. Appendiceal carcinoid tumors. Rev Bras Coloproctol. 2000;20:9-13.

7. Cheng JY, Lin JC, Yu DS, Lee WH, Meng CL. Flow cytometric DNA analysis of colorectal carcinoid. Am J Surg. 1994;168:29-32.

8. de Herder WW. Tumours of the midgut (jejunum, ileum and ascending colon, including carcinoid syndrome). Best Pract Res Clin Gastroenterol. 2005;19:705-15.

9. Federspiel BH, Burke AP, Sobin LH, Shekitka KM. Rectal and colonic carcinoids. A clinicopathologic study of 84 cases. Cancer. 1990;65:135-40.

10. Gerstle JT, Kauffman GL Jr., Koltun WA. The incidence, management, and outcome of patients with gastrointestinal carcinoids and second primary malignancies. J Am Coll Surg. 1995; 180:427-32.

11. Greenstein AJ, Balasubramanian S, Harpaz N, Rizwan M, Sachar DB. Carcinoid tumor and inflammatory bowel disease: a study of eleven cases and review of the literature. Am J Gastroenterol. 1997;92:682-5.

12. Habal N, Sims C, Bilchik AJ. Gastrointestinal carcinoid tumors and second primary malignancies. J Surg Oncol. 2000;75:310-6.

13. Herman P, Santoro S, Simonsen O, Habr-Gama A, Cerri GG, Pinotti HW, Magalhães A. Tumor de cólon com invasão gástrica: relato de caso e aspectos clínico-radiológicos. Rev Imagem. 1989;11:23-5

14. Jiao YF, Nakamura S, Arai T, Sugai T, Uesugi N, Habano W, Suzuki M, Tazawa $\mathrm{H}$, Goukon Y. Adenoma, adenocarcinoma and mixed carcinoid-adenocarcinoma arising in a small lesion of the colon. Pathol Int. 2003;53:457-62.

15. Jotz GP, Abramovich MP, Couto MA, Pereira JL, Schamaedecke AA, Wallau CH Carcinoid of Meckel's diverticulum: report of a case and review of the literature. Arq Gastroenterol. 1990;27:30-2.

16. Kang H, O’Connell JB, Leonardi MJ, Maggard MA, McGroy ML, Ko CY. Rare tumors of the colon and rectum: a national review. Int $\mathrm{J}$ Colorectal Dis. 2007;22:183-9.

17. Knight BK, Hayes MM. Mixed adenocarcinoma and carcinoid tumour of the colon. A report of 4 cases with postulates on histogenesis. S Afr Med J. 1987;72:708-10.
18. Konishi T, Watanabe T, Kishimoto J, Kotake K, Muto T, Nagawa H. Prognosis and risk factors of metastasis in colorectal carcinoids: results of a nationwide registry over 15 years. Gut. 2007;56:863-8.

19. Kuroda N, Nakayama H, Miyazaki E, Toi M, Hiroi M, Enzan H. The distribution of CD34-positive stromal cells and myofibroblasts in colorectal carcinoid tumors. Histol Histopathol. 2005;20:27-33.

20. Lauffer JM, Zhang T, Modlin IM. Current status of gastrointestinal carcinoids [review article]. Aliment Pharmacol Ther. 1999;13:271-87.

21. Lyda MH, Fenoglio-Preiser CM. Adenoma-carcinoid tumors of the colon. Arch Pathol Lab Med. 1998;122:262-5.

22. Mangueira PA, Fernandes GO, Primo CC, França MA, Maia HP, Costa JH Rectal carcinoid tumor. Rev Bras Coloproctol. 2006;26:162-7.

23. Modlin IM, Sandor A. An analysis of 8305 cases of carcinoid tumors. Cancer 1997;79:813-29.

24. Modlin IM, Kidd M, Latich I, Zikusoka MN, Shapiro MD. Current status of gastrointestinal carcinoids. Gastroenterology. 2005;128:1717-51.

25. Onaitis MW, Kirshbom PM, Hayward TZ, Quayle FJ, Feldman JM, Seigler HF, Tyler DS. Gastrointestinal carcinoids: characterization by site of origin and hormone production. Ann Surg. 2000;232:549-56.

26. Rosenberg JM, Welch JP. Carcinoid tumors of the colon. A study of 72 patients Am J Surg. 1985;149:775-9.

27. Roumeliotis A, Barkas K, Amygdalos G. Carcinoid: modern aspects on its therapy. Tech Coloproctol. 2004;8(suppl 1):s164-6.

28. Shebani KO, Souba WW, Finkelstein DM, Stark PC, Elgadi KM, Tanabe KK, Ott MJ. Prognosis and survival in patients with gastrointestinal tract carcinoid tumors. Ann Surg. 1999;229:815-21.

29. Smith DM Jr., Haggitt RC. The prevalence and prognostic significance of argyrophil cells in colorectal carcinomas. Am J Surg Pathol. 1984;8:123-8.

30. Soybel DI, Bliss DP Jr., Wells SA Jr. Colon and rectal carcinoma. Curr Prob Cancer. 1987:11:257-356

31. Spread C, Berkel H, Jewell L, Jenkins H, Yakimets W. Colon carcinoid tumors A population-based study. Dis Colon Rectum. 1994;37:482-91

32. Tichansky DS, Cagir B, Borrazzo E, Palazzo J, Weaver EJ, Lange A, Fry RD. Risk of second cancers in patients with colorectal carcinoids. Dis Colon Rectum. 2002;45:91-7.

33. Virgolini I, Raderer M, Kurtaran A, Angelberger P, Banyai S, Yang Q, Li S Banyai M, Pidlich J, Niederle B, Scheithauer W, Valent P. Vasoactive intestinal peptide-receptor imaging for the localization of intestinal adenocarcinomas and endocrine tumors. N Engl J Med. 1994;331:1116-21

34. Waisberg J, Hamada M, Goncalves JE, Messias M, Bromberg SH, Jatobá PP, Godoy AC. Carcinoid tumors of the gastrointestinal tract. Analysis of 21 cases Arq Gastroenterol. 1990;27:53-61. 